\title{
The association of subclinical inflammation and early repolarization patterns observed in healthy Turkish males
}

\section{Sağlıklı erkek bireylerde saptanan erken repolarizasyon paternleri'nin subklinik inflamasyon ile ilişkisi}

\section{Burak Hüinük}

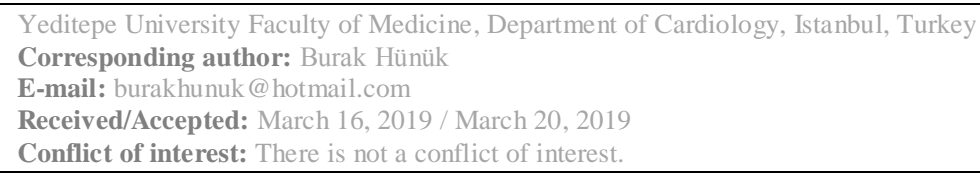

\section{SUMMARY}

Objective: Early repolarization pattern (ER) on surface ECG has recently been associated with an increased risk of sudden cardiac death (SCD) due to lethal ventricular arrhythmias. Inflammatory markers such as high-sensitive-Creactive peptide (hs-CRP) have been linked with an increased risk of SCD and cardiac morbidity in numerous publications for various cardiovascular settings. However, data about the relationship between the inflammatory markers and ER is scarce. We sought to evaluate the relationship of subclinical inflammatory markers and the presence of ER on healthy Turkish males.

Materials and Methods: 180 healthy male volunteers between $\geq 18$ to $\leq 50$ years old without any cardiac/systemic disorders were evaluated for our study. Supine surface ECG, complete blood count, hs-CRP, Erythrocyte sedimentation rate (ESR) and serum electrolytes were obtained. Subjects with complete-bundle-branch-blocks, non-sinus-rhythms and any abnormality on cardiac examination were excluded. ER was defined as J-point elevation of $\geq 0.1 \mathrm{mV}$ in $\geq 2$ leads in the inferior (II, III, aVF) (Inferior ER), lateral (DI, aVL, V4-6) (Lateral ER) or both (Inferolateral ER) leads.

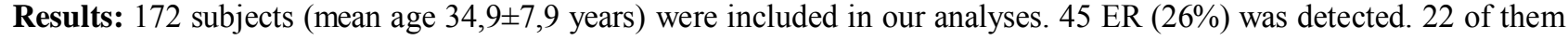
were lateral $(49 \%), 13$ was inferior $(29 \%)$ and 10 of them were $(22 \%)$ inferolateral ER. ER+ subjects had significantly higher hs-CRP levels $(\mathrm{mg} / \mathrm{dl}$, mean $\pm \mathrm{SD})(\mathrm{ER}-1.7 \pm 1.8$ vs ER+ 3.1 $\pm 2.9, \mathrm{p}<0.01)$. No significant association could be demonstrated with other inflammatory parameters. In the subgroup analyses, only inferior ER was significantly associated with higher hs-CRP levels compared with the ER - population, while hs-CRP levels of subjects with lateral and infero-lateral ER was not significantly higher (ER- $1.7 \pm 1.8$ vs Inferior ER $4.5 \pm 3.1, p<0,01$ ). In multivariate analyses, high hs-CRP levels were significantly predicting the presence of ER (Odds ratio: 1,24; \%95 CI: 1,06 - 1,46; $\mathrm{p}$ $=0,008)$.

Conclusions: Subclinical inflammation might influence the prevalence of ER on young healthy males. Suggestively more malignant Inferior ER seems to be mainly associated with the high hs-CRP levels in Turkish male population. This finding might be attributed to the experimentally demonstrated effects of inflammation on various cardiac ion channel functions taking part in the cardiac action potential.

Keywords: C-reactive peptide, early repolarization pattern, electrocardiogram, male, complete blood count. 
Amaç: Yüzey EKG'de saptanan Erken Repolarizasyon paternleri (ER) son zamanlarda ölümcül ventriküler aritmiler ve artmış ani kardiyak ölüm (AKÖ) riski ile ilişkilendirilmiştir. Yüksek duyarlılığa sahip c-reaktif peptid (hs-CRP) gibi enflamatuar belirteçler, çeşitli kardiyovasküler hastalıklar için pek çok yayında artmış AKÖ riski ve kardiyak morbidite ile ilişkili bulunmuştur. Ancak, enflamatuar belirteçler ve ER arasındaki olası ilişki hakkındaki veriler azdır. Bu çalışmada, subklinik inflamatuar belirteçlerin ve ER'nin sağl1klı Türk erkek bireylerdeki varlığının ilişkisini değerlendirmeyi amaçladık.

Yöntem: Çalışmamızda herhangi bir kalp / sistemik hastalığı olmayan $\geq 18$ ila $\leq 50$ yaş arası 180 sağlıklı erkek gönüllü değerlendirildi. Katılımcıların supin yüzey EKG, tam kan sayımı, hs-CRP, eritrosit sedimantasyon hızı ve serum elektrolitleri tespit edildi. Tam dal bloğu, sinus-dışı ritmi ve kardiyak muayenede herhangi bir anormalliği bulunan denekler çalışma dışı bırakıldı. Belirli EKG derivasyonlarının $\geq 2$ 'sinde $\geq 0,1 \mathrm{mV}$ olan J-nokta yüksekliği İnferior ER (II, III, aVF), Lateral ER (DI, aVL, V4-6) ve Inferolateral ER(II, III, aVF, DI, aVL, V4-6) olarak tanımlandı.

Bulgular: Analizlere 172 denek (ortalama yaş 34,9 \pm 7,9 y1l) dahil edildi. Çalıșma EKG'lerinde 45 ER (\% 26) tespit edildi. 22'si lateral (\% 49), 13 'ü inferior (\% 29) ve 10'u (\% 22) inferolateral ER idi. ER + deneklerde hs-CRP düzeyleri anlamlı olarak yüksek bulundu (mg / dl, ortalama $\pm \mathrm{SD}$ ) $(\mathrm{ER}-1.7 \pm 1.8$ vs ER $+3.1 \pm 2.9, \mathrm{p}<0.01)$. Diğer enflamatuar parametrelerle anlamlı ilişki gösterilemedi. Alt grup analizlerinde, sadece inferior ER, ER saptanmayan popülasyona kıyasla daha yüksek hs-CRP düzeyleri ile anlamlı olarak ilişkiliyken, lateral ve inferolateral ER'li hastaların hs-CRP düzeyleri anlamlı olarak yüksek değildi (ER- $1.7 \pm 1.8$ vs İnferior ER $4.5 \pm 3.1, \mathrm{p}<0,01$ ). Çok değişkenli analizlerde, yüksek hs-CRP seviyeleri ER'nin varlığını anlamlı olarak tahmin ediyordu (Odds oranı: 1,24;\% 95 Güven Aralığı: 1,06 $1,46 ; \mathrm{p}=0,008)$.

Sonuç: Subklinik enflamasyon, ER'nin genç sağlıklı erkeklerdeki saptanma prevalansını etkileyebilir. Daha malign bir patern olarak düşünülen İnferior ER, esas olarak Türk erkek popülasyonundaki yüksek hs-CRP seviyeleri ile ilişkili görünmektedir. Bu bulgu, inflamatuar süreçlerin, kardiyak aksiyon potansiyelinde yer alan çeşitli kardiyak iyon kanalı fonksiyonları üzerindeki deneysel olarak gösterilmiș etkilerine atfedilebilir.

Anahtar sözcükler: c-reaktif-peptid, elektrokardiyogram, erkek cinsiyet, erken repolarizasyon paterni, tam kan sayımı

\section{INTRODUCTION}

Early repolarization pattern (ER) which is defined as an elevation of the junction between the end of the QRS complex and the beginning of the ST segment (the J-point) from isoelectric line in leads except V1 to V3 on surface ECG has traditionally been considered as a benign finding, however it has recently been associated with an increased risk for sudden cardiac death and lethal ventricular arrhythmias (VA) ${ }^{1,2}$. The presence of ER has been shown as a sign for increased mortality and morbidity in numerous cardiac conditions recently, such as coronary artery disease ${ }^{3}$ and heart failure ${ }^{4}$. The prevalence of ER considerably ranges between $1 \%-5 \%$ to $35 \%$, depending on age (predominant in young athletic adults), sex (prevalent in males), race (common in black populations) and by definition of ERP on that specific cohort (i.e. J-point elevation $>0,05$ or $0,1 \mathrm{mV}$ or more $)^{2,5-7}$. In general population, the inferior/infero-lateral distribution of ERPs with horizontal/downsloping ST segments has previously been shown to suggest an increased risk of lethal VA whereas lateral ER especially presenting with upsloping ST-segments have not predicted any increased risk of lethal arrhythmia ${ }^{1,2,5-9}$. ER with documented VA is defined as Early Repolarization Syndrome and is grouped in a spectrum called "J wave Syndromes" including Brugada Syndrome and Idiopathic Ventricular Fibrillation sharing similar physiopathological characteristics such as mutations in the genes leading to loss of function in cardiac $\mathrm{Na}^{+}$and $\mathrm{Ca}^{+2}$ channels as well as to a gain of function in $\mathrm{K}^{+}$ channels $\left[\mathrm{I}_{\text {to }} \text { or (ATP dependent) } \mathrm{I}_{\mathrm{K}-\mathrm{ATP}}\right]^{5}$.

There is substantial amount of evidence demonstrating that inflammatory processes are firmly linked to the initiation, development and deterioration of cardiovascular diseases ${ }^{10}$. Elevated levels of inflammatory markers, especially C-reactive peptide (CRP), have previously been shown to be predictive of future cardiovascular events manifesting a dominant subclinical and occult ongoing inflammatory state ${ }^{10,11}$. Even though their role is less defined than atherosclerotic processes, the significance of inflammatory markers has also recently been implicated in various arrhythmic events ${ }^{12,13}$. Inflammatory mediators has been shown to effect the functions of potassium and L-type-calcium channels taking part in the action potential of myocardial excitable cells predominantly leading to a prolonged action potential duration which might be considered as a good substrate for atrial and ventricular malignant arrhythmias ${ }^{13}$. Regarding the effects of inflammation in J-WaveSyndromes, the prognosis of Brugada Syndrome seems to be closely related with the acute or chronic inflammatory states, making the prognosis grimmer as the inflammatory markers, especially CRP, are found to be increased ${ }^{14,15}$. However, to our knowledge, there is no clinical research on the Western literature specifically designed to define the effects of inflammation on ER. 
Herein; we sought to evaluate the relationship of some contemporary subclinical inflammatory markers that has previously been shown to have an effect on cardiovascular health such as $\mathrm{CRP}^{10}$, neutrophil to lymphocyte ratio ${ }^{16}$, uric acid ${ }^{17}$, inflammatory complete-blood-count (CBC) parameters ${ }^{18}$ and the presence of ER on healthy Turkish males with an aim to investigate a possible link between the poor prognostic cardiovascular features and the markers of inflammation that can easily be reached and checked in a routine clinical setting.

\section{METHODS}

180 healthy male volunteers between $\geq 18$ to $\leq 50$ years old without any previously known or diagnosed cardiac or systemic disorders and no acute inflammatory complaints or clinical findings consistent with acute inflammation were prospectively and consecutively evaluated for participation in our study. The study complies with the Declaration of Helsinki, patients provided signed informed consent prior to the procedures and the local ethical committee approval obtained.

Supine 12-lead surface ECG, complete blood count, high sensitivity (hs)-CRP, Erythrocyte sedimentation rate (ESR), lipid profile, serum uric acid, renal function tests and serum electrolytes were obtained together with thorough physical examination. Subjects with complete bundle branch blocks on ECG, non-sinus rhythms and any abnormal findings on cardiac examination were excluded from the study.

\section{Electrocardiographic assessment}

The 12-lead ECGs were recorded at $25 \mathrm{~mm} / \mathrm{s}$ with a calibration of $10 \mathrm{~mm} / \mathrm{mV}$ and uploaded on the hospital ECG database at 300 DPI. These images were amplified x 10 and then baseline heart rates, PR, QRS, QTc (Bazett) intervals were manually measured by electronic calipers. The presence of a lateral (I, aVL, V5-V6), inferior (II, III, aVF) or infero-lateral (II, III, aVF, I, aVL, V5-V6) ER was defined as an evident J-point elevation of at least $1 \mathrm{~mm}(0.1 \mathrm{mV})$ above the isoelectric line in at least two consecutive leads with either QRS slurring (i.e. a smooth transition from the end QRS to the beginning of ST-segment) or notching [positive deflection (J-wave) occurring immediately after a positive QRS complex at the onset of the ST-segment]. We stuck to the most recently proposed terminology from the latest international consensus documents for the ECG definition of ER 9,19, and "J peak" was accepted as
"J point" denoting the peak of a notch or onset of a slur. All the ECGs were analysed by the author in a blinded fashion for the laboratory findings of the patients with borderline results being reassessed by another experienced cardiologist.

\section{Blood tests and analysis}

Venous blood samples were drawn with patients after they rest supine for about $15 \mathrm{~min}$ prior to sampling. Samples were drawn atraumatically without venous stasis through a 21-gauge cannula inserted into an antecubital vein using ethylenediamine tetraacetic acid containing monovettes (Sarstedt, Nuembrecht, Germany), and transferred immediately to the laboratory to be centrifuged. Hs-CRP level was measured on Cobas Integra 400 Plus using a latex particleenhanced immunoturbidimetric assay following the manufacturer's instructions (Roche Diagnostics, Indianapolis, IN). The measuring range for this assay was $0.01-20 \mathrm{mg} / \mathrm{dL}$. The ESR was determined by Westergren's method. The complete blood counts were evaluated using an auto-analyzer Sysmex XT-1800i Hematology Analyzer (Sysmex Corporation, Kobe, Japan). Neutrophil to lymphocyte ratio was calculated as the ratio of neutrophils to lymphocytes from these results. The remaining routine biochemistry parameters have been determined by the core laboratory.

\section{Statistical analysis}

Continuous variables are expressed as mean $\pm \mathrm{SD}$ (if the parameter is normally distributed) or standard error of mean (SEM $\pm \mathrm{SD})$ whichever is suitable. If appropriate, they were compared using the Student's t-test. Categorical variables are expressed as numbers and percentages and, if appropriate, were compared with the Chi-square analysis. Univariate and later multivariate analysis was performed to determine the predictive value of significant and predetermined confounders on the ER observations using the Cox regression model. A p value $<0.05$ was accepted statistically significant. Statistical analysis was performed using SPSS 20.0 (IBM Inc., Armonk, New York, USA).

\section{RESULTS}

Out of 180 volunteers, 172 male subjects (mean age $34,9 \pm 7,9$ years) were included in our analyses after the application of inclusion criteria. ER (+) subjects were significantly younger, had a lower basal heart rate, longer PR interval and had significantly higher hs-CRP levels compared with the ones without (Table-1). In total, 45 ER (26\%) 
was detected on ECG. 22 of them were lateral (49\%), 13 was inferior (29\%) and 10 of them were (22\%) inferolateral ER (Figure-1 to 3). However, no significant association could be demonstrated with ESR, white blood cell count, neutrophil to lymphocyte ratio and uric acid levels. In the subgroup analyses, only Inferior ER was significantly associated with higher hs-CRP levels compared with the ER (-) population, while hsCRP levels of subjects with lateral and inferolateral ER was not significantly higher (Table-2). In univariate analyses, high hs-CRP levels were significantly predicting the presence of ER (Odds ratio: 1,$24 ; \% 95$ CI: $1,06-1,46 ; p=0,008)$. In the model including Age, BMI, Uric acid, NLR and hs-CRP, multivariate regression analysis was performed and hs-CRP was found to be the most significant parameter to predict the presence of ER on ECG even outperforming "Age" which had also qualified in the analysis until last step with a borderline significance level as well (Table-3).

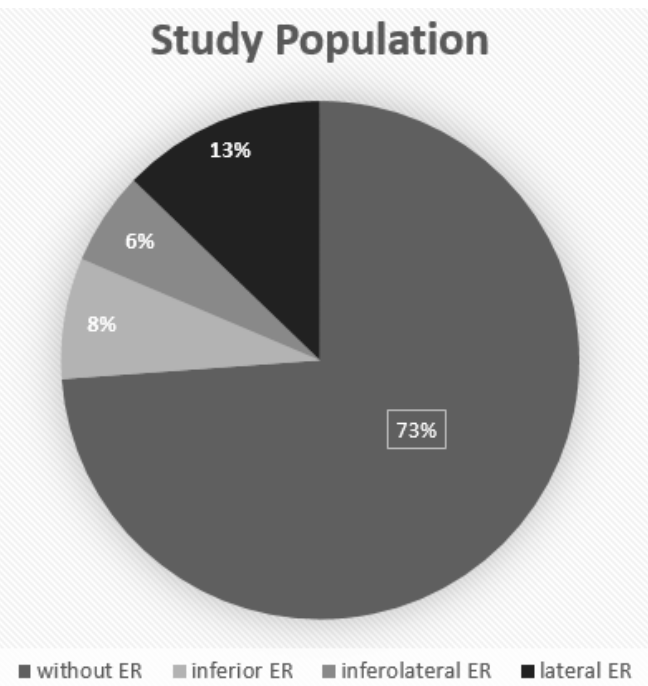

Figure 1. Prevalence and the distribution of early repolarization patterns in study population.

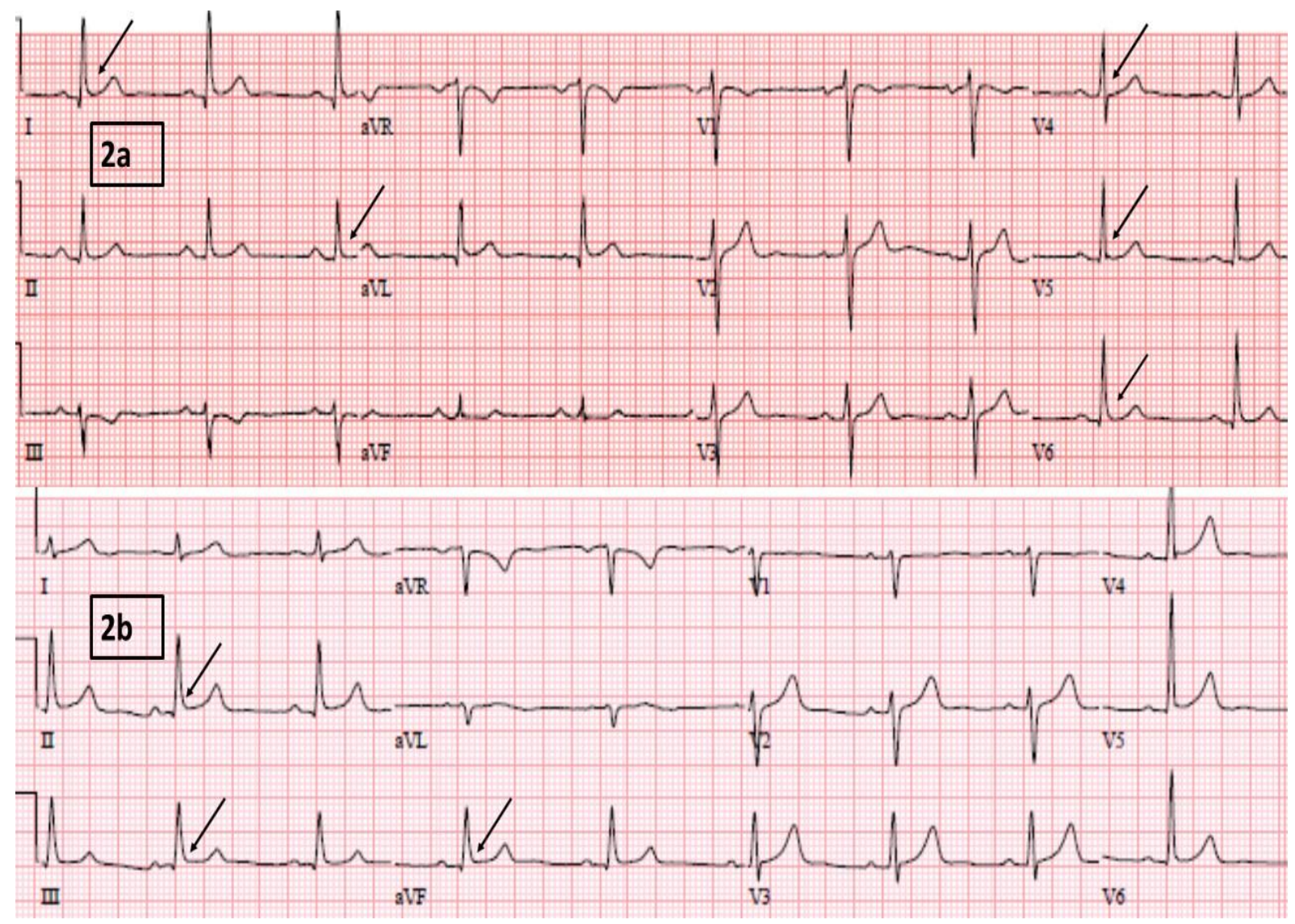

Figure 2-2a: Lateral early repolarization pattern example. Arrows indicate QRS slurring with around $2 \mathrm{~mm} \mathrm{~J}$ point elevation followed by upsloping benign ST segment changes. 2b: Inferior early repolarization pattern example. Arrows indicate QRS slurring with around $1 \mathrm{~mm} \mathrm{~J}$ point elevation and a malignant type horizontal ST segment elevation is followed. 
Table 1. Baseline parameters of the population with and without early repolarization pattern.

\begin{tabular}{|c|c|c|c|}
\hline & ER (-) & ER (+) & \multirow{2}{*}{$P$ value } \\
\hline Number of subjects & $(\mathrm{n}=127)$ & $(\mathrm{n}=45)$ & \\
\hline Age (years) & $35.5 \pm 8.1$ & $32.6 \pm 6.8$ & 0.03 \\
\hline Weight (kg) & $83.1 \pm 11.3$ & $81.2 \pm 11.2$ & 0.87 \\
\hline Height $(\mathrm{cm})$ & $176.1 \pm 5.6$ & $176.6 \pm 4.5$ & 0.31 \\
\hline Body mass index $\left(\mathrm{kg} / \mathrm{m}^{2}\right)$ & $26.7 \pm 3.2$ & $26.1 \pm 3.6$ & 0.23 \\
\hline \multicolumn{4}{|l|}{ Electrocardiogram } \\
\hline Heart rate (b.p.m & $73.9 \pm 11.5$ & $68.4 \pm 10.3$ & $<0.001$ \\
\hline QTc duration (ms) & $404.4 \pm 18.3$ & $404.1 \pm 14.5$ & 0.89 \\
\hline PR duration (ms) & $153.9 \pm 20.3$ & $163.3 \pm 21.6$ & 0.01 \\
\hline QRS duration (ms) & $90.4 \pm 11.2$ & $91.9 \pm 10.2$ & 0.30 \\
\hline \multicolumn{4}{|l|}{ Laboratory results } \\
\hline Glucose $(\mathrm{mg} / \mathrm{dL})$ & $86.8 \pm 10.9$ & $86.6 \pm 10.6$ & 0.93 \\
\hline BUN (mg/dL) & $29.2 \pm 7.0$ & $29.4 \pm 7.0$ & 0.84 \\
\hline Creatinin $(\mathrm{mg} / \mathrm{dL})$ & $0.91 \pm 0.12$ & $0.88 \pm 0.10$ & 0.14 \\
\hline Uric acid $(\mathrm{mg} / \mathrm{dL})$ & $5.3 \pm 1.0$ & $5.4 \pm 1.0$ & 0.83 \\
\hline Sodium $(\mathrm{mmol} / \mathrm{L})$ & $143.1 \pm 2.4$ & $142.9 \pm 2.4$ & 0.66 \\
\hline Potassium (mmol/L) & $4.5 \pm 0.3$ & $4.6 \pm 0.3$ & 0.49 \\
\hline Hemoglobin (g/dL) & $14.5 \pm 0.9$ & $14.4 \pm 0.7$ & 0.47 \\
\hline Platelet count $\left(10^{s} / \mu \mathrm{L}\right)$ & $233.2 \pm 57.7$ & $234.4 \pm 49.6$ & 0.91 \\
\hline White blood cell count $\left(10^{5} / \mu \mathrm{L}\right)$ & $5.97 \pm 1.4$ & $5.62 \pm 1.11$ & 0.13 \\
\hline Neutrophil $\left(10^{5} / \mu \mathrm{L}\right)$ & $3,15 \pm 1.01$ & $2.86 \pm 0.89$ & 0.09 \\
\hline Lymphocyte $\left(10^{3} / \mu \mathrm{L}\right)$ & $2.03 \pm 0.46$ & $1.88 \pm 0.53$ & 0.09 \\
\hline Neutrophil-to-lymphocyte ratio (\%) & $1.5 \pm 0.4$ & $1.7 \pm 0.7$ & 0.30 \\
\hline High sensitive C-reactive protein $(\mathrm{mg} / \mathrm{L})$ & $1.7 \pm 1.8$ & $3.1 \pm 2.9$ & $<0.001$ \\
\hline Erythrocyte sedimentation rate $(\mathrm{mm} / \mathrm{h})$ & $6.9 \pm 4.7$ & $8.3 \pm 6.2$ & 0.14 \\
\hline Total cholesterol (mg/dL) & $184.1 \pm 35.5$ & $180.1 \pm 29.8$ & 0.51 \\
\hline HDL (mg/dL) & $41.2 \pm 8.6$ & $43.1 \pm 10.0$ & 0.27 \\
\hline $\mathrm{LDL}(\mathrm{mg} / \mathrm{dL})$ & $112.9 \pm 27.9$ & $110.0 \pm 24.5$ & 0.56 \\
\hline Triglycerides $(\mathrm{mg} / \mathrm{dL})$ & $145.9 \pm 82.6$ & $129.1 \pm 63.4$ & 0.23 \\
\hline \multicolumn{4}{|c|}{$\begin{array}{l}\text { Abbreviation: } \quad \text { ER: Early repolarization pattern } \\
\text { Values are mean } \pm \text { Standard error of the mean (SEM). } \\
\text { Statistically significant }(p<0.05) \text {. }\end{array}$} \\
\hline
\end{tabular}

Table 2. Association of hs-CRP levels with subgroups of early repolarization patterns compared with subjects without early repolarization.

\begin{tabular}{|l|l|l|}
\hline Parameters & hs-CRP level $(\mathrm{mg} / \mathrm{dl}$, mean $\pm \mathrm{SD})$ & p value \\
\hline No ER & $1.7 \pm 1.8$ & \\
\hline Inferior ER $(\mathrm{n}=13)$ & $4.5 \pm 3.1$ & $\mathbf{0 . 0 1}$ \\
\hline Inferolateral ER $(\mathrm{n}=10)$ & $2.1 \pm 2.2$ & 0.98 \\
\hline Lateral ER $(\mathrm{n}=22)$ & $2.6 \pm 2.9$ & 0.24 \\
\hline
\end{tabular}

Abbreviation: ER: Early repolarization pattern, hs-CRP: High-sensitive C-reactive peptide 


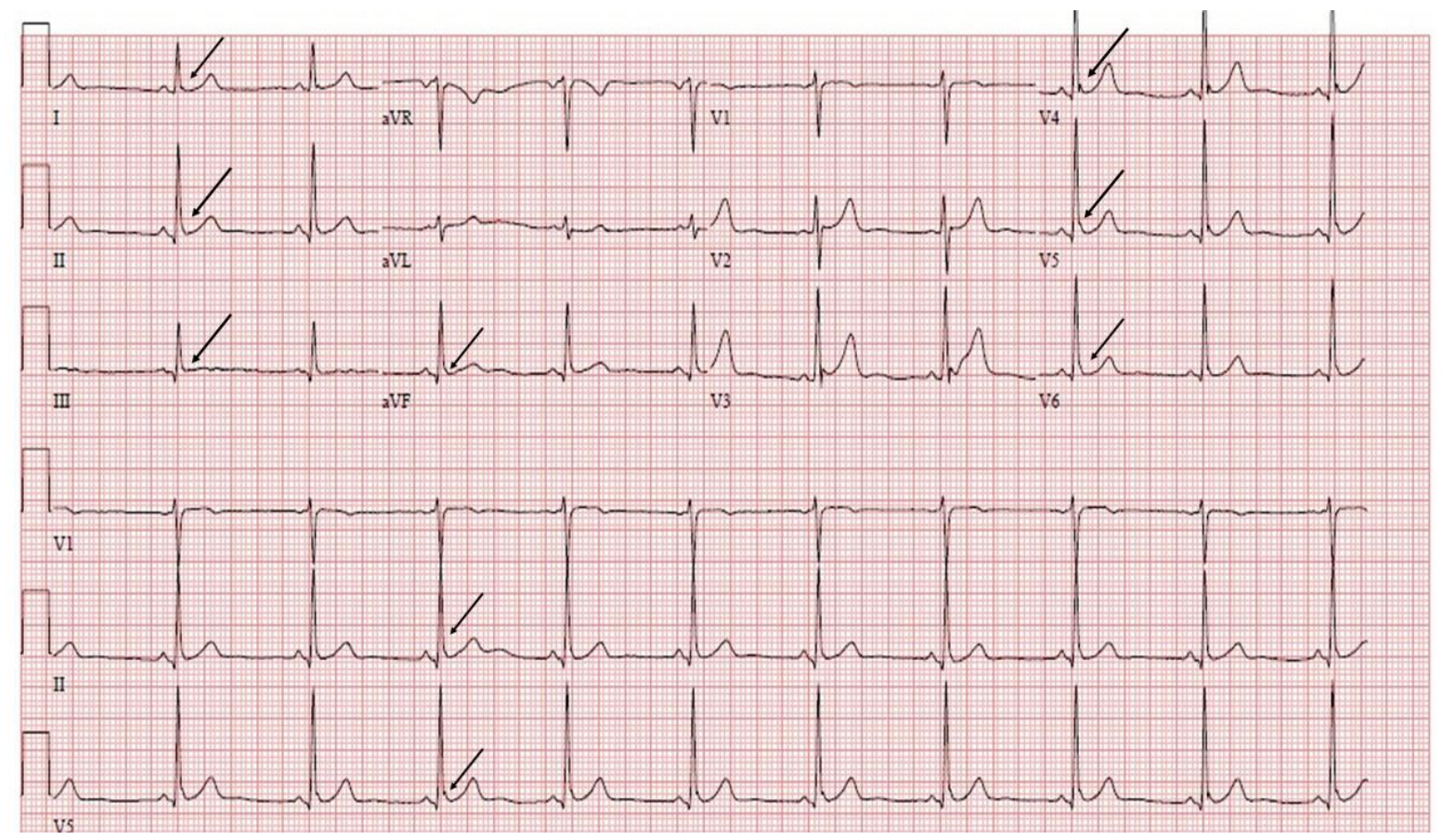

Figure 3: Inferolateral early repolarization pattern. Arrows indicate QRS slurring with around $1 \mathrm{~mm} \mathrm{~J}$ point elevation and a benign type upsloping ST segment elevation is followed in inferior leads and QRS notching on lateral leads followed by upslope ST elevations most evident on V4 to V5.

Table 3. Multivariate Cox Regression Analysis to predict early repolarization on surface ECG.

\begin{tabular}{cccc}
\hline Parameters & Odds ratio & 95\% confidence interval & p value \\
\hline Age & 0,95 & $0,90-1.01$ & 0,05 \\
hs-CRP & 1,24 & $\mathbf{1 , 0 6}-\mathbf{1 , 4 5}$ & $\mathbf{0 , 0 0 8}$ \\
BMI & 0,95 & $0,85-1,07$ & 0,486 \\
ESR & 1,01 & $0,94-1,09$ & 0,725 \\
Uric acid & 1.01 & $0,69-1.47$ & 0.966 \\
NLR & 1.36 & $0,69-2.71$ & 0.370 \\
\hline Abbreviations: CRP: high-sensitive-C-reactive peptide, BMI: Body mass index, ESR : Erythrocyte \\
sedimentation rate, NLR: Neutrophil / Lymphocyte ratio.
\end{tabular}

\section{DISCUSSION}

In our young male study group, we detected a ER prevalence of $\% 26$ and a lateral ER predominance which was consistent with the findings of the previous similar age and gender matched Western population based studies ${ }^{7}$. The ones with ER were significantly demonstrating ECG parameters reflecting a somewhat higher vagal tone (relatively low basal heart rate, longer PR interval) compared with the ones without ER, a finding also compatible with the previous population based studies and proposed ER mechanisms ${ }^{5,7,9,19}$. We intentionally have chosen to work with a young male population in order to increase our chance to reveal ER on surface ECG and to prevent possible confounder systemic or structural problems which might eventually cause data loss while working on a rare ECG sign. Highsensitivity-CRP levels were significantly higher in the ER(+) group and this significance was mainly occurring because of the inferior ER subgroup. High hs-CRP levels were strongly and 
significantly predicting the presence of ER in a multivariate regression model of previously known confounders/predictors of ER and cardiac risk including young age.

\section{Clinical and mechanistic aspects of ER}

Previous studies put forward that all ER types does not represent the same cardiovascular phenotype and some types are more closely associated with an increased arrhythmic risk. Observations from population-based studies with a long follow-up suggest that ER observed on lateral leads carries the lowest risk and might be accepted as a real normal-variant whereas risk progressively increases with inferior ERP and prominently increases in combined infero-lateral $\mathbf{J}$ wave distribution ${ }^{8,20}$. In $\mathbf{J}$ wave syndromes, main mechanism leading to ERs and Brugada pattern is explained by an outward shift in cardiac action potential repolarizing current due to a decrease in $\mathrm{Na}^{+}$or $\mathrm{Ca}^{+2}$ channel currents or an increase in outward currents ( $\mathrm{I}_{\mathrm{to}}, \mathrm{I}_{\mathrm{K}-\mathrm{ATP}}, \mathrm{I}_{\mathrm{K}-\mathrm{ACh}}$, or other) giving rise to a transmural voltage gradient between endocardium and epicardium on partial regions of the heart leading to lethal ventricular arrhythmias ${ }^{5}$.

\section{Clinical and electrophysiological impact of inflammation:}

It has recently been demonstrated that, cardiovascular morbidity is significantly increased in patients with chronic inflammatory states with a prevalence of ischemic heart disease and heart failure 1.5 to 2 times higher than in the general population ${ }^{13,21,22}$ Furthermore, also the coronary atherosclerotic burden and SCD, regardless of the extent and starting time of clinical atherosclerosis, is significantly increased in chronic inflammatory states like rheumatoid arthritis ${ }^{23}$. Likewise, large prospective community-based research have also demonstrated that inflammatory markers, particularly high-sensitivity hs-CRP and IL-6, are strong and independent predictors of SCD and atrial fibrillation in apparently healthy subjects 24,25 . Although, the progression of coronary atherosclerosis might sound as the most probable underlying mechanism, it is also possible that low-grade systemic inflammation may be per se pro-arrhythmogenic by inducing cytokinemediated structural and electric myocardial remodelling, and subsequently chronic cardiac sympathetic activation. Accordingly, populationbased studies established that significant association exists between inflammatory markers, and QT-interval, heart rate variability on 24-h Holter recordings and P-wave-dispersion abnormalities ${ }^{26,27}$. This suggests that the link between arrhythmic events and inflammation may be partly explained by electrophysiological changes occurring in both ventricular and atrial myocardium.

\section{Proposed common cellular electrophysiological cascades:}

It has previously been shown on a basic research study that, perfused hearts from transgenic mice overexpressing $\mathrm{TNF} \alpha$ exhibited a prolonged action potential duration (APD) and re-entrant ventricular arrhythmias ${ }^{28}$; ventricular myocytes isolated from these animals strikingly demonstrated a robust decrease of the transient outward current (Ito), and a reduced expression of the corresponding potassium-channel protein $^{29}$. Moreover, it was also shown that TNF $\alpha$ down-regulates in vitro the rapid component of the delayed rectifier potassium current (IKr) by impairing the hERG potassium-channel function. In addition, experiments on pig and mouse ventricular cells proved that also IL-6 and IL-1 prolong APD, by enhancing L-type calcium current $^{30}$. Most recently, Stumpf et al. ${ }^{31}$ nicely demonstrated that athletes with an ER on ECG had significantly higher atrial filling pressures, higher LA volume, and higher IL-6 plasma levels, demonstrating the structural and molecular acute effects of pronounced inflammatory states.

All the above mentioned studies point to the ionic mechanisms which are already very actively taking part in the formation of the transmural voltage gradient that we see as typical ST segment elevations and $\mathrm{j}$ point notches in some specific parts of the heart in all types of ER, sometimes giving rise to dangerous phase- 2 reentries and torsade-de-pointes episodes ${ }^{5,9,19,32,33}$. Hence, mechanistically it seems logical and appropriate to intervene any pronounced inflammatory state more aggressively in patients especially with $\mathrm{j}$ wave syndromes and malignant $\mathrm{j}$-wave patterns. Future studies designed to investigate this aim would probably yield more data on our theorical suggestion based on our data and evidence based mechanisms about ER.

\section{Limitations:}

In our study we only considered the admittance surface ECG and the dynamic character of the ER patterns ${ }^{5}$ was our major limitation leading to a probable underestimation. This aspect of the $j$ wave phenomenon will always be there in the clinical studies conducted on this concept because of its susceptibility to the ever changing 
vagal/hormonal tonus and environmental factors like temperature, ${ }^{5,9}$. We tried to overcome this underestimation problem by trying to conduct our study on young and male volunteers and hypothetically increasing our expected ER prevalence. It would also be better to look for the $\mathrm{Na}$ and $\mathrm{K}$ channel mutations in the ER group for causal definitions. Even though our study design was cross-sectional, it might be good to follow the patients with high hs-CRP and ER to see the ECGs again after the hs-CRP levels normalized.

\section{CONCLUSIONS}

Subclinical inflammation seems to influence the prevalence of ER on young healthy males. Inferior ER, as a supposedly malignant ER type is determined to be mainly associated with the high hs-CRP levels in young Turkish male population. This finding might be attributed to the experimentally demonstrated effects of inflammation on various cardiac ion channel functions taking part in the cardiac action potential and on the pathophysiology and the lethal ventricular events observed in ER syndromes. Arrhythmogenic potential of the inflammatory states has recently been more popular with the aging population and with the ever growing number of patients with chronic systemic and degenerative diseases ${ }^{13,21}$. However, the mechanistic pathways and the measures to be taken in order to prevent the bad outcomes for this seemingly important phenomenon still waits to be defined.

\section{REFERENCES}

1. Haïssaguerre M, Derval N, Sacher F, Jesel L, Deisenhofer I, de Roy L, et al. Sudden Cardiac Arrest Associated with Early Repolarization. N Engl J Med [Internet]. 2008 May 8 [cited 2018 Nov 5];358(19):2016-23. Available from: http://www.ncbi.nlm.nih.gov/pubmed/184 63377

2. Tikkanen JT, Anttonen O, Junttila MJ, Aro AL, Kerola T, Rissanen HA, et al. LongTerm Outcome Associated with Early Repolarization on Electrocardiography. $\mathrm{N}$ Engl J Med [Internet]. 2009 Dec 24 [cited 2018 Nov 5];361(26):2529-37. Available from: http://www.ncbi.nlm.nih.gov/pubmed/199 17913

3. Patel RB, Ng J, Reddy V, Chokshi M, Parikh K, Subacius H, et al. Early repolarization associated with ventricular arrhythmias in patients with chronic coronary artery disease. Circ Arrhythm Electrophysiol [Internet]. 2010 Oct [cited 2018 Nov 5];3(5):489-95. Available from: https://www.ahajournals.org/doi/10.1161/ CIRCEP.109.921130

4. Furukawa Y, Yamada T, Morita T, Iwasaki Y, Kawasaki M, Kikuchi A, et al. Early repolarization pattern associated with sudden cardiac death: long-term follow-up in patients with chronic heart failure. $\mathbf{J}$ Cardiovasc Electrophysiol [Internet]. 2013 Jun [cited 2018 Nov 5];24(6):632-9. Available from: http://doi.wiley.com/10.1111/jce.12093

5. Antzelevitch C. J wave syndromes: molecular and cellular mechanisms. J Electrocardiol [Internet]. 2013 Nov [cited 2018 Nov 5];46(6):510-8. Available from: https://linkinghub.elsevier.com/retrieve/pii/ S0022073613004123

6. Maury P, Rollin A. Prevalence of early repolarisation/J wave patterns in the normal population. $\mathrm{J}$ Electrocardiol [Internet]. 2013 Sep [cited 2018 Nov 5];46(5):411-6. Available from: https://linkinghub.elsevier.com/retrieve/pii/ S002207361300335X

7. Patton KK, Ellinor PT, Ezekowitz $M$, Kowey P, Lubitz SA, Perez M, et al. Electrocardiographic Early Repolarization. Circulation [Internet]. 2016 Apr 12 [cited 2018 Nov 5];133(15):1520-9. Available from:

http://www.ncbi.nlm.nih.gov/pubmed/270 67089

8. Tikkanen JT, Huikuri H V. Characteristics of "malignant" vs. "benign" electrocardiographic patterns of early repolarization. J Electrocardiol [Internet]. 2015 May [cited 2018 Nov 5];48(3):390-4. Available from: https://linkinghub.elsevier.com/retrieve/pii/ S0022073614005081

9. Macfarlane PW, Antzelevitch C, Haissaguerre M, Huikuri H V., Potse M, Rosso R, et al. The Early Repolarization Pattern: A Consensus Paper. J Am Coll Cardiol [Internet]. 2015 Jul 28 [cited 2018 Nov 5];66(4):470-7. Available from: https://www.sciencedirect.com/science/arti cle/pii/S073510971502478X?via\%3Dihub

10. Ruparelia N, Chai JT, Fisher EA, Choudhury RP. Inflammatory processes in cardiovascular disease: a route to targeted therapies. Nat Rev Cardiol [Internet]. 2017 [cited 2019 Jan 26];14(3):133-44. Available from: 
http://www.ncbi.nlm.nih.gov/pubmed/279 05474

11. Dhingra R, Gona P, Nam B-H, D'Agostino RB, Wilson PWF, Benjamin EJ, et al. Creactive protein, inflammatory conditions, and cardiovascular disease risk. Am J Med [Internet]. 2007 Dec [cited 2019 Jan 26];120(12):1054-62. Available from: http://www.ncbi.nlm.nih.gov/pubmed/180 60926

12. Streitner F, Kuschyk J, Veltmann C, Ratay D, Schoene N, Streitner I, et al. Role of proinflammatory markers and NT-proBNP in patients with an implantable cardioverter-defibrillator and an electrical storm. Cytokine [Internet]. 2009 Sep [cited 2019 Jan 26];47(3):166-72. Available from:

http://www.ncbi.nlm.nih.gov/pubmed/196 04708

13. Lazzerini PE, Capecchi PL, Laghi-Pasini F. Systemic inflammation and arrhythmic risk: lessons from rheumatoid arthritis. Eur Heart J [Internet]. 2016 Jun 1 [cited 2019 Jan 26];38(22):ehw208. Available from: http://www.ncbi.nlm.nih.gov/pubmed/272 52448

14. Bonny A, Tonet J, Márquez MF, De Sisti A, Temfemo A, Himbert C, et al. Creactive protein levels in the brugada syndrome. Cardiol Res Pract [Internet]. 2011 [cited 2019 Jan 24];2011:341521. Available from: http://www.ncbi.nlm.nih.gov/pubmed/222 03916

15. Li A, Tung R, Shivkumar K, Bradfield JS. Brugada syndrome-Malignant phenotype associated with acute cardiac inflammation? Hear case reports [Internet]. 2017 Aug [cited 2019 Jan 26];3(8):384-8. Available from: http://www.ncbi.nlm.nih.gov/pubmed/288 40105

16. Karavelioğlu Y, Karapınar H, Yüksel M, Memiç K, Sarak T, Kurt R, et al. Neutrophil to Lymphocyte Ratio is Predictor of Atrial Fibrillation Recurrence After Cardioversion With Amiodarone. Clin Appl Thromb [Internet]. 2015 Jan 14 [cited 2019 Jan 26];21(1):5-9. Available from:

http://www.ncbi.nlm.nih.gov/pubmed/244 31383

17. Muiesan ML, Agabiti-Rosei C, Paini A, Salvetti M. Uric Acid and Cardiovascular Disease: An Update. Eur Cardiol [Internet]. 2016 Aug [cited 2019 Jan
26];11(1):54-9. Available from: http://www.ncbi.nlm.nih.gov/pubmed/303 10447

18. Twig G, Afek A, Shamiss A, Derazne E, Tzur D, Gordon B, et al. White blood cell count and the risk for coronary artery disease in young adults. PLoS One [Internet]. 2012 [cited 2019 Jan 26];7(10):e47183. Available from: http://www.ncbi.nlm.nih.gov/pubmed/230 77568

19. Calkins H, Hindricks G, Cappato R, Kim Y-H, Saad EB, Aguinaga L, et al. 2017 HRS/EHRA/ECAS/APHRS/SOLAE

CE expert consensus statement on catheter and surgical ablation of atrial fibrillation: Executive summary. EP Eur [Internet]. 2018 Jan 1 [cited 2018 Nov 20];20(1):157$208 . \quad$ Available from: http://www.ncbi.nlm.nih.gov/pubmed/290 16841

20. Haïssaguerre M, Derval N, Sacher F, Jesel L, Deisenhofer I, de Roy L, et al. Sudden Cardiac Arrest Associated with Early Repolarization. N Engl J Med [Internet]. 2008 May 8 [cited 2018 Nov 5];358(19):2016-23. Available from: http://www.nejm.org/doi/abs/10.1056/NEJ Moa071968

21. Klingenberg R, Lüscher TF. Rheumatoid arthritis and coronary atherosclerosis: two cousins engaging in a dangerous liaison. Eur Heart J [Internet]. 2015 Dec 21 [cited 2019 Jan 26];36(48):3423-5. Available from:

http://www.ncbi.nlm.nih.gov/pubmed/264 43024

22. Gabriel SE. Cardiovascular Morbidity and Mortality in Rheumatoid Arthritis. Am J Med [Internet]. 2008 Oct [cited 2019 Jan 26];121(10):S9-14. Available from: http://www.ncbi.nlm.nih.gov/pubmed/189 26169

23. Karpouzas GA, Malpeso J, Choi T-Y, Li D, Munoz S, Budoff MJ. Prevalence, extent and composition of coronary plaque in patients with rheumatoid arthritis without symptoms or prior diagnosis of coronary artery disease. Ann Rheum Dis [Internet]. 2014 Oct 1 [cited 2019 Jan 26];73(10):1797-804. Available from: http://www.ncbi.nlm.nih.gov/pubmed/238 87286

24. Hussein AA, Gottdiener JS, Bartz TM, Sotoodehnia N, DeFilippi C, See V, et al. Inflammation and sudden cardiac death in a community-based population of older 
adults: The Cardiovascular Health Study. Hear Rhythm [Internet]. 2013 Oct [cited 2019 Jan 26];10(10):1425-32. Available from:

http://www.ncbi.nlm.nih.gov/pubmed/239 06927

25. Empana J-P, Jouven X, Canouï-Poitrine F, Luc G, Tafflet M, Haas B, et al. CReactive Protein, Interleukin 6, Fibrinogen and Risk of Sudden Death in European Middle-Aged Men: The PRIME Study. Arterioscler Thromb Vasc Biol [Internet]. 2010 Oct [cited 2019 Jan 26];30(10):204752. Available from: http://www.ncbi.nlm.nih.gov/pubmed/206 51278

26. Medenwald D, Kors JA, Loppnow H, Thiery J, Kluttig A, Nuding S, et al. Inflammation and Prolonged QT Time: Results from the Cardiovascular Disease, Living and Ageing in Halle (CARLA) Study. Zirlik A, editor. PLoS One [Internet]. 2014 Apr 25 [cited 2019 Jan 24];9(4):e95994. Available from: http://www.ncbi.nlm.nih.gov/pubmed/247 70373

27. Sajadieh A, Nielsen OW, Rasmussen V, Hein HO, Abedini S, Hansen JF. Increased heart rate and reduced heart-rate variability are associated with subclinical inflammation in middle-aged and elderly subjects with no apparent heart disease. Eur Heart J [Internet]. 2004 Mar [cited 2019 Jan 26];25(5):363-70. Available from:

http://www.ncbi.nlm.nih.gov/pubmed/150 33247

28. London B, Baker LC, Lee JS, Shusterman V, Choi B-R, Kubota T, et al. Calciumdependent arrhythmias in transgenic mice with heart failure. Am J Physiol Circ Physiol [Internet]. 2003 Feb [cited 2019 Jan 26];284(2):H431-41. Available from: http://www.ncbi.nlm.nih.gov/pubmed/123 88316
29. Petkova-Kirova PS, Gursoy E, Mehdi H, McTiernan CF, London B, Salama G. Electrical remodeling of cardiac myocytes from mice with heart failure due to the overexpression of tumor necrosis factor- $\alpha$. Am J Physiol Circ Physiol [Internet]. 2006 May [cited 2019 Jan 26];290(5):H2098107. Available from: http://www.ncbi.nlm.nih.gov/pubmed/163 39842

30. Hagiwara Y, Miyoshi S, Fukuda K, Nishiyama N, Ikegami Y, Tanimoto K, et al. SHP2-mediated signaling cascade through gp130 is essential for LIFdependent $\mathrm{ICaL},[\mathrm{Ca} 2+] \mathrm{i}$ transient, and APD increase in cardiomyocytes. $\mathrm{J}$ Mol Cell Cardiol [Internet]. 2007 Dec [cited 2019 Jan 26];43(6):710-6. Available from: http://www.ncbi.nlm.nih.gov/pubmed/179 61593

31. Stumpf C, Simon $M$, Wilhelm $M$, Zimmermann S, Rost C, Achenbach S, et al. Left atrial remodeling, early repolarization pattern, and inflammatory cytokines in professional soccer players. J Cardiol [Internet]. 2016 Jul [cited 2019 Jan 24];68(1):64-70. Available from: https://linkinghub.elsevier.com/retrieve/pii/ S0914508715002713

32. Miyazaki S, Shah AJ, Haïssaguerre M. Early Repolarization Syndrome. Circ J [Internet]. 2010 [cited 2011 Jul 3];74(10):2039-44. Available from: http://joi.jlc.jst.go.jp/JST.JSTAGE/circj/CJ -10-0753?from=CrossRef

33. Haïssaguerre M, Sacher F, Nogami A, Komiya N, Bernard A, Probst V, et al. Characteristics of Recurrent Ventricular Fibrillation Associated With Inferolateral Early Repolarization. J Am Coll Cardiol [Internet]. 2009 Feb [cited 2018 Nov 5];53(7):612-9. Available from: http://linkinghub.elsevier.com/retrieve/pii/ S0735109708038035 